\title{
Assessment of Passenger Health Before Air Travel
}

\author{
Havayoluyla Seyehat Öncesi Yolcu Sağlığının Değerlendirilmesi
}

\author{
Mehmet Ali Ceyhan', (D) Gultekin Gunhan Demir ${ }^{2}$ \\ 1- Sağlık Bilimleri Üniversitesi, Ankara Şehir Hastanesi, Acil Tıp Kliniği, Bilkent, Ankara, Turkey. 2- İstanbul Medipol Üniversitesi Kardiyoloji \\ Ana Bilim Dalı, İstanbul, Turkey.
}

\begin{abstract}
The number of the passenger using air travel keeps increasing every year. Inconsistency with an increasing number of passengers without medical conditions, the number of passengers with acute or chronic medical conditions increases inevitably. The attitude of commercial aircrafts providing passenger transportation during air travel is associated with altered internal cab pressure, humidity rate, partial oxygen pressure when compared with sea level pressure and medium. Alterations in the internal cab during a flight are usually well tolerated by healthy passengers, however might harm passengers with acute or chronic medical conditions. Around $65 \%$ of health conditions emerging during flights are related to pre-existing medical conditions. Passengers with medical conditions are not fully aware of the potential influences of flight on their acute or chronic conditions. However, treatment options are substantially limited in case of an emergent medical condition during flights. Evaluation and clearance of patients with medical conditions before the flight by physicians experienced in-flight medicine is the key step for elimination or minimizing risks during the flight. Particularly patients with a history of recent hospitalization, injury, surgery, unstable conditions related to chronic health conditions, acute conditions, need for oxygen support, need for stretcher should be thoroughly evaluated before the flight. The present review aimed to investigate preflight medical screening of patients with medical conditions and their risks associated with air travel.

ÖZET

Havayolu ile seyahat yapan yolcu sayısı her yıl artmaya devam etmektedir. Sağlı problemi olmayan yolcularla birlikte akut veya kronik hastalığı olan yolcu sayısının artması da kaçınılmazdır. Yolcu taşımacılığ yapan ticari havayolu uçaklarının uçtuğu yükseklikte, uçak içi kabin ortamı, deniz seviyesindeki çevresel ortamından farklıdır ve kabin içi basınç, parsiyel oksijen basıncı, nem oranı gibi değişiklikler meydana gelir. Havayoluyla seyahat süresince uçak içi kabin ortamındaki değişiklikler sağlıkl yolcular tarafindan tolere edilirken, akut veya kronik sağlık problemi olan yolcuları kötü yönde etkileyebilmekte ve hastalık șiddeti artabilmektedir. Uçuş sürecinde meydana gelen sağlık sorunlarının yaklaşık olarak \%65'i yolcunun seyahat öncesinde var olan hastalığının kötüleșmesi sonucu meydana gelmektedir. Sağllk problemi olan yolcular genellikle havayolu ile seyahatin akut veya kronik hastalığı üzerine etkisinin ne düzeyde olacağının bilincinde değildir. Ancak uçuş esnasında herhangi bir sağlık problemi gelişmesi durumunda tedavi seçenekleri oldukça kısıtlıdır. Havayolu seyahati öncesi sağlık sorunu olan yolcuların, uçuş öncesi havacılık tıbbında tecrübeli doktorlar tarafindan değerlendirilerek uçuşuna izin verilmesi, uçuş esnasında yolcuların sağllk probleminin kötüleșmesini en aza indirme ve riskleri önlemede esastır. Özellikle yakın zamanda hastaneye yatış gerektiren sağlık problemi olan, yaralanma, cerrahi operasyon, akut olarak gelişen veya var olan kronik hastalığın anstabil olduğu dönemler, oksijen kullanımı, sedye gibi özel hizmet gerektiren yolcular, teşhis veya hastanede tedavi amacıyla yurt içi veya yurt dişı seyahat eden yolcuların, havayoluyla seyahat öncesi uçuşa uygunluğu değerlendirilmelidir. Bu derlemede sağllk problemi olan yolcuların uçuş öncesi değerlendirilmesi ve bu yolcuların havayoluyla seyahat etmesinin riskleri gözden geçirildi.
\end{abstract}

\author{
Keywords: \\ Air travel, \\ Preflight medical screening, \\ Passenger health.
}

\author{
Anahtar Kelimeler: \\ Havayolu seyahati, \\ Uçuş öncesi sağlık taraması, \\ Yolcu sağlı̆̆l.
}

\section{GíRiş}

Havayolu ile seyahat yapan yolcu sayısı her yıl artmaya devam etmektedir (1). Sağlik problemi olmayan yolcularla birlikte akut veya kronik hastalı̆̆ sayısının artmasıda kaçınılmazdır. Yolcu taşımacığı yapan ticari havayolu uçaklarının uçtuğu yükseklikte, uçak içi kabin ortamı, deniz seviyesindeki çevresel ortamdan farklıdır ve kabin içi basınç, parsiyel oksijen basıncı $\left(\mathrm{pO}_{2}\right)$, nem oranında değişiklikler meydana gelir. Havayoluyla seyahat süresince uçak içi kabin ortamındaki değişiklikler sağlıklı yolcular tarafından tolere edilirken, akut veya kronik sağlık problemi olan yolcuları kötü yönde etkileyebilmekte ve hastalık şiddeti artabilmektedir $(2,3)$. Uçuş sürecinde meydana gelen sağlık sorunlarının yaklaşık olarak \%65'i yolcunun seyahat öncesinde var olan hastalığının kötüleşmesi sonucu meydana gelmektedir (4). Sağllk problemi olan yolcular, genellikle havayolu ile seyahatin akut veya kronik hastalığı üzerine etkisinin ne düzeyde olacağının bilincinde değildir (5). Ancak uçuş esnasında herhangi bir sağlı problemi gelişmesi durumunda tedavi seçenekleride oldukça kısıtlıdır. Havayolu seyahati öncesi sağlık sorunu olan yolcuların, uçuş öncesi havacılık tıbbında tecrübeli doktorlar tarafindan değerlendirilerek uçuşuna izin verilmesi, uçuş esnasında 
yolcuların sağlık probleminin kötüleşmesini en aza indirme ve riskleri önlemede esastır $(2,3)$. Özellikle yakın zamanda hastaneye yatış gerektiren sağlık problemi olan, yaralanma, cerrahi operasyon, akut olarak gelişen hastalıklar veya var olan kronik hastalığın anstabil olduğu dönemler, oksijen $\left(\mathrm{O}_{2}\right)$ kullanımı, sedye gibi özel hizmet gerektiren yolcular, teşhis veya hastanede tedavi amacıyla yurt içi veya yurt dışı seyahat eden yolcuların, havayoluyla seyehat öncesi uçuşa uygunluğu değerlendirilmelidir.

$\mathrm{Bu}$ derlemede sağlık problemi olan yolcuların uçuş öncesi değerlendirilmesi ve bu yolcuların havayoluyla seyahat etmesinin riskleri gözden geçirildi.

\section{1- YÜKSEK İRTIFADA UÇUŞUN ETKILLERİ VE UÇAK IÇi KABIN ORTAMINDAKI DEĞișíiKLIKER}

Yüksek irtifada yolcu sağlığını olumsuz etkileyen kabin içi değişiklikler; kabin içi basıncında ve parsiyel oksijen basıncında düşme, kapalı vücut bölgelerindeki hava hacminin genişlemesi, kabin içi nem oranında düşme, sıkışık oturma ve hareketin kısıtlanması, kabin içi kirli havanın yenilenmesidir (2,6-8).

1.1- Kabin Basıncında ve $\mathrm{PO}_{2}$ 'de Düşme: Havayolu ile seyahatlerde uçuş yüksekliğinin artmasının en önemli etkisi barometrik basıncın düşmesidir. Tüm ticari uçaklarda kabin içi basınç hiçbir zaman için deniz seviyesindeki atmosfer basıncına eşitlenemez ve yüksek irtifada kabin içi basıç deniz seviyesindeki atmosfer basıncından düşüktür (6). Ticari olarak yolcu taşımacılığ 1 yapan uçaklar yaklaşık olarak 21 bin-40 bin fit (ft) irtifada uçar ve yükseklik arttıkça kabin içi basınç düşer. Uçağın uçuş yüksekliği 21 bin-40 bin ft olsada kabin içi basınç, uçağın 5000-8000ft (1500-2450 m) yükseklikte uçtuğu kabin içi basıncına ayarlanır $(5,9)$. Deniz seviyesinde atmosfer basinc $760 \mathrm{mmHg}, \mathrm{pO}_{2}=$ 96-98 mmHg iken 5000-8000 ft (1500-2450 m) yüksekliğe eşdeğer kabin basıncı ise $565 \mathrm{mmHg}$, $\mathrm{pO}_{2}=55$ mmHg'a düşer $(7,9)$. Kabin içi basıncın düşmesiyle eş zamanlı olarak $\mathrm{pO}_{2}$ düşer ve hipobarik hipoksisemi meydana gelir. Sağlıklı kişilerde kabin içi basınçdaki azalmaya bağlı olarak oksijen saturasyonu $\left(\mathrm{SatO}_{2}\right)$ yaklaşık olarak \%3-4 düşer. Kabin içinde oluşan hipoksi sağlıklı yolcularda fizyolojik değişikliklerle (dakikadaki solunum sayısı, kalp hızı ve kardiyak output artışı gibi) kompanze edilir. Ancak kabin içi basınç değeri 10 bin $\mathrm{ft}(3050 \mathrm{~m})$ yükseklikteki kabin basıncına eşdeğer düşerse ki 6 saatten uzun süreli uçuşlarda ve kıtalar arası uçuşlarda bu irtifa daha sık aşılır ve hipoksi daha belirgin hale gelir (10). Bu durumda sağlıklı kişilerde $\mathrm{SatO}_{2}$ yaklaşık olarak \%89'a düşer, hipoksiye bağlı semptomlar başlar ve ilave oksijen kullanılması gerekir. Sağlıklı kişilerde ilave oksijen verilmesi hipoksiyle ilişkili semptomları düzeltebilmektedir (7). Ancak deniz sevisyesindeki atmosfer basıncinda azalmış $\mathrm{pO}_{2}$ 'ye sahip olan yolcularda, kabin içi basıncındaki azalma daha düşük $\mathrm{pO}_{2}$ ile sonuçlanır ve risk daha fazla artar (7).
1.2-Kapalı Vücut Bölgelerindeki Hava Hacminin Genişlemesi: Uçuş esnasında irtifa artarken meydana gelen kabin içi barometrik basınç düşmesinin diğer önemli majör etkisi hava hacminin genişlemesidir. Yüksek irtifaya çıkış ve inişlerde hava hacmindeki değişiklikler çok hızlı meydana gelir. Yüksek irtifa uçuşlarında kapalı vücut alanlarındaki havanın hacmi yaklaşık olarak \%30-40 genişlemektedir $(2,11,12)$. Sonuç olarak kapalı vücut boşluklarındaki patolojik hava (ileus, pnömosefali, pnömotoraks vb) ve fizyolojik hava (orta kulak, sinüs içi hava gibi) genişlemektedir $(2,6)$. Örneğin abdominal cerrahi sonrasında ileus tablosu gelişmişse yüksek irtifada hava genişlemesi sonucu, bu hastalarda sütür yerlerinde yırtılma, kanama, perferasyon riski sözkonusu olmakta, gastrik ve intestinal mukozada gerilme sütür veya ülser yerlerinden kanama ile sonuçlanabilmektedir $(3,9,11,12)$.

1.3-Kabin İçi Düşük Nem Oranı: Aşırı yükseklerde atmosfer havasının nem oranı düşer. Kabin içi hava değişimi büyük oranda motorlardan geçen atmosfer havasıyla sağlanır ve bu havadaki nem oranı \%1'den azdır. Yolcuların ve mürettebatın solunum havasındaki nemle, uçak mutfağı ve tuvaletlerden gelen nemin etkisi ile kabin içi nem oranı \%10-20 arasında değişir. Bu nem oranı ise ideal bir ortam oluşturmaz $(2,6)$. Düşük neme bağlı havayolu pasajlarında, kornea (özellikle kontakt lens kullananlar) ve deride nem kaybı sonucu irritasyon ve kaşıntı meydana gelir (6).

1.4-Sıkışık Oturma ve Hareket Kısıtlanması: Yolcuların dar ve sıkışık koltuklarda oturması, kabin içinde yürüme ve germe hareketlerinin yapılmasını kısıtlar. Bu durum periferik ödem, kramp ve diğer periferik dolaşım hastalıklarının şiddetlenmesine neden olabildiği gibi bulaşıcı hastalık riskinide artırabilir $(3,13)$.

1.5-Kabin İçi Hava Değişimi: Kabin içi havanın yenilenmesi, yaklaşık olarak $\% 50$ oranında dış ortam havasının motorlardan geçerek uçak içine verilmesiyle ve $\% 50$ oranında uçak içi havanın yüksek verimli partikül filtrelerinden (HEPA) geçirildikten sonra tekrar kabin içine verilmesi ile sağlanır $(2,6)$. Kabin içinde hava değişim sürecinde hava akım yönü yukarıdan (tavandan) aşağıya doğrudur, uçağın ön tarafindan arka tarafina doğru değildir $(6,8)$. Bu nedenle enfekte bir hastanın kabin içindeki tüm yolcuları hava sirkülasyonuna bağlı enfekte etme riski düşüktür ancak yakınında oturan yolcuyu enfekte etme riski vardır $(3,8)$.

\section{2-UÇUŞ ÖNCESİ GENEL DEĞERLENDİRME}

Yolcular mutlaka uçuşun kesin kontrendike olduğu akut veya kronik hastalık yönünden değerlendirilmelidir (Tablo-1). Akut veya yakın zamanda gelişen sağlık problemi olan yolcularda yolcunun uçuşa uygun olup olmadığını değerlendirirken, hastalığın ortaya çıkışı ile planlanan uçuş tarihi arasında geçen zaman dilimi esas alınır. Bu zaman dilimi herbir hastanın bireysel 
Tablo 1: Havayoluyla Seyahatin Kontrendikasyonlar1*

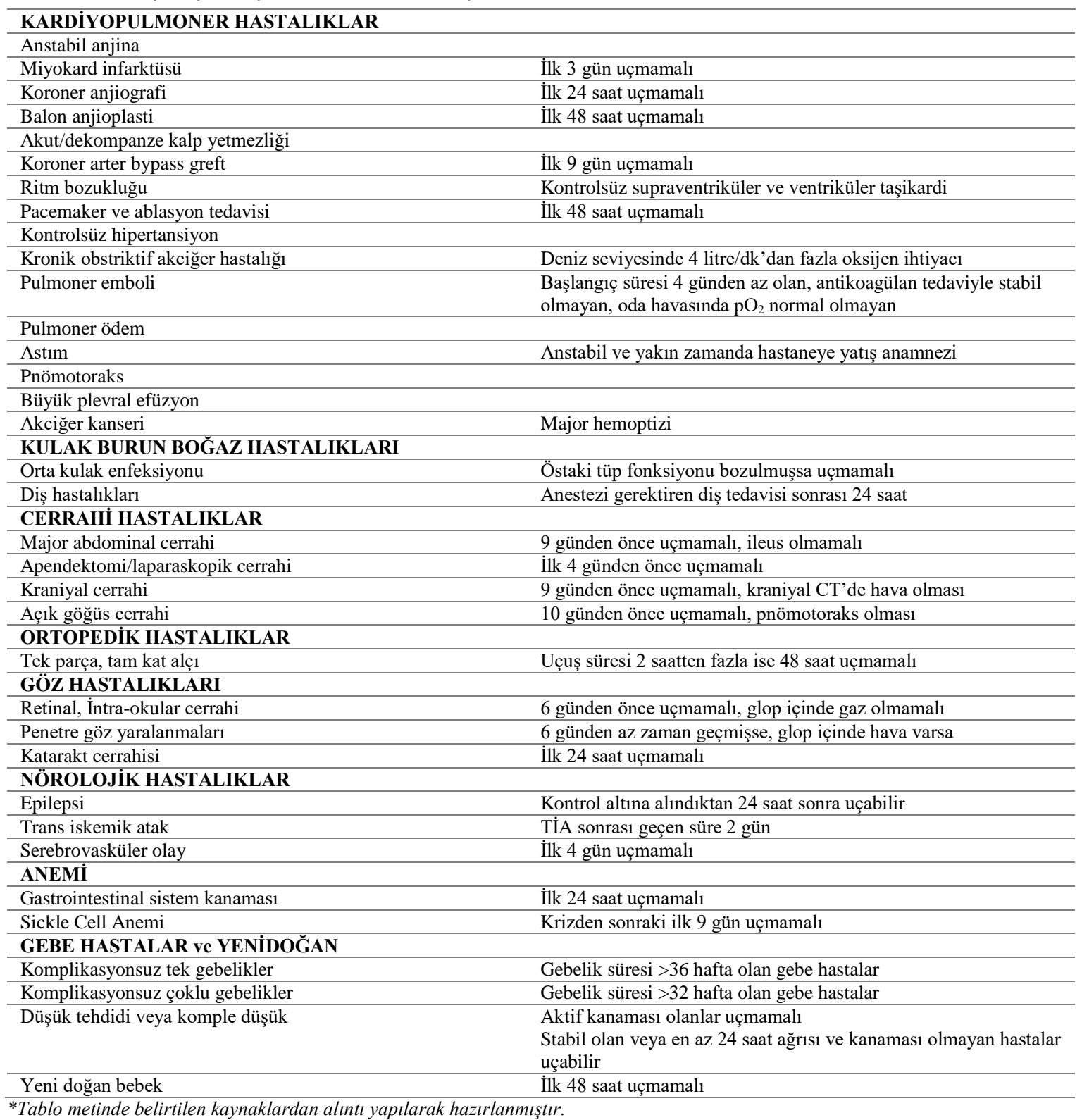

değerlendirme sonuçlarına göre artabilir veya azalabilir (6).

Kronik hastalığı olan yolcularda, yolcunun uçuşa uygun olup olmadığını değerlendirirken, yüksek irtifada oluşacak kabin içi ortam değişikliklerinin, yolcunun hastalığı üzerine olumsuz etkisinin olup olmayacağı, kronik hastalık zemininde yakın zamanda gelişen anstabil bir durum ve ilave $\mathrm{O}_{2}$ kullanımının gerekip gerekmeyeceği değerlendirilmelidir $(2,3)$.

\section{3-KARDİYOVASKÜLER HASTALIKLAR}

Kardiyovasküler hastalığı olan yolcular için en büyük endişe yüksek irtifada kabin içi basınç ve $\mathrm{pO}_{2}$ 'nin düşmesi sonucu meydana gelen hipoksidir (9). Hipoksiye primer kardiyak cevap taşikardidir ve buda miyokardiyal $\mathrm{O}_{2}$ talebini artırır (9). Dakikadaki solunum sayısı ve tidal volümu artışıla uçuş hipoksisi kompanze edilir. Ancak kardiyak rezervi sınırlı olan hastalar hipoksiyi kompanze edemez ve semptomlar meydana gelebilir (9). Ayrıca uçuş stresi ve heyecan da kardiyak rezervi sinırlı olan hastalarda semptomları artırabilmektedir (9).

3.1-Anjina Pektoris; Anstabil anjinalı hastaların uçması kesin olarak kontendikedir $(12,14)$. Anstabil anjinası veya minimal efor ile anjinası olan yolcular uçuş öncesi havacılık tıbbı alanında tecrübeli doktorlar tarafından değerlendirildikten sonra uçup uçmayacağına karar verilmelidir $(6,14)$.

İstirahatte anjinası olmayan veya ilaçlarla kontrol edilebilen stabil anjinalı hastalar ilaçlarını yanlarında taşıdıkları müddetçe ve tedaviye uyum gösterdikleri müddetçe uçmalarında sakınca yoktur $(3,6)$. 
3.2- Miyokard İnfarktüsü (Mİ); Akut Mİ sonras1 düşük risk grubundaki hastalar (yaş<65, ilk defa Mí, başarılı reperfüzyon, $\mathrm{EF}>45 \%$, komplikasyon yok, daha ileri araştırma veya girişimsel işlem gerektirmeyen) 3 gün sonra, orta risk grubundaki hastalar ( $\mathrm{EF}>40 \%$, komplikasyon yok, daha ileri araştırma veya girişim gerektirmeyen, eforla iskemi bulguları veya aritmisi olmayan) 10 gün sonra havacilık tıbbı alanında tecrübeli doktorlar tarafindan değerlendirildikten sonra uçuşuna izin verilebilir $(2,6,15)$. Yüksek risk grubundaki hastaların $(\mathrm{EF}<40 \%$, yetmezilik semptom ve bulgusu olan, yakın zamanda ileri araştırma, girişimsel olarak revaskülarizasyon gerektiren) uçuşu ertelenmelidir (6).

3.3-Koroner Anjiografi; Anjiografi sonrası geçen süre süre 24 saatten az olan yolcular uçuş öncesi havacıllk tıbb1 alanında tecrübeli doktorlar tarafindan değerlendirilmelidir (6). Anjiografi öncesi durumu stabil olan ve anjiografi sonrası geçen süre 24 saatten fazla olan yolcuların uçmasında sakınca yoktur (6). Stent konsun veya konmasin balon anjioplasti sonrasi geçen süre 2 günden az olan yolcular uçuş öncesi havacılık tıbbı alanında tecrübeli doktor tarafindan değerlendirilmelidir (6). Balon anjioplasti sonrası geçen süre 3 günden fazla olan ve herhangi bir semptomu olmayan yolcuların uçmasında sakınca yoktur $(2,6,12,15)$.

3.4- Konjestif Kalp Yetmezliği (KKY); Akut kalp yetmezliği ve dekompanze KKY olan yolcuların uçması kontrendikedir $(3,6,9)$. KKY olan yolcular uçuş öncesi değerlendirilmeli ve baseline $\mathrm{pO}_{2}<70 \mathrm{mmHg}$ olan veya Class III-IV KKY olan yolculara uçuş esnasında $\mathrm{O}_{2}$ verilmesi önerilmelidir (9). Kalp yetmezliği kontrol altında ve stabil olan yolcuların uçmasına izin verilebilir. İleri tetkik ve değerlendirme imkanlarının kısıtlı olduğu durumlarda pratikte kullanılabilecek bir değerlendirme ise; KKY olan hasta stabilse, semptom olmaksızın $50 \mathrm{~m}$ yürüyebiliyorsa veya oda havasında solunum sıkıntısı olmaksızın normal adımlarla bir kat merdivenden çıkabiliyorsa uçuşa elverişli olarak değerlendirilebilir (6).

3.5-Koroner Arter Bypass Greft (KABG) Cerrahisi ve Diğer Kardiyak Cerrahiler; KABG, kapak, transpozisyon, atriyal ve ventriküler septal defekt, kardiyak transplantasyon cerrahisi sonrası geçen süre 9 günden az olan hastalar uçuş öncesi havacilık tıbbı alanında tecrübeli doktorlar tarafindan değerlendirilmelidir (6). Bu hastalar ameliyat sonrası geçen süre 10 günden fazla ise, herhangi bir komplikasyon meydana gelmemişse, KKY, ciddi aritmi ve iskemi açısından değerlendirildikten sonra uçabilirler $(3,6,9)$.

3.6-Kalp Kapak Hastalıkları; Semptomatik kalp kapak hastalıkları uçuş için rölatif kontrendikasyon oluşturur (9). Kalp kapak hastalıkları olan yolcular, uçuş öncesi klinik olarak değerlendirilmeli, fonksiyonel durumu, semptomların şiddeti, ejeksiyon fraksiyonu, pulmoner hipertansiyonun varlı̆g 1 veya yokluğu açısından değerlendirilmelidir (6,9). Uçuş öncesi değerlendirmede hipoksemisi olan hastalara uçuş süresince ilave oksijen verilmesi önerilmelidir (9).

3.7-Ritim Bozuklukları ve Kardiyak Pacemaker; Kontrolsüz supraventriküler ve ventriküler taşikardi uçuş için kontrendikasyon oluşturur $(9,12)$. Pacemaker veya intrakardiyak defibrilatör (ICD) implantasyonu sonrasinda pnömotoraks yoksa, ritim stabilse ve 2 günden fazla zaman geçmişse bu yolcuların uçmasında sakınca yoktur (6). Ablasyon tedavisi sonrası 2 günden fazla zaman geçmişşe bu yolcuların uçmasında sakınca yoktur (6).

3.8-Hipertansiyon (HT); HT kontrol altında olduğu müddetçe uçuş için kontrendikasyon oluşturmaz. Ancak HT'u olan yolcular ilaçlarını yanlarında taşımalıdır. Kontrolsüz HT uçuş için kontrendikasyon oluşturur $(9,12)$.

\section{4-SOLUNUM SISTEMİ HASTALIKLARI}

Solunum sistemi hastalığı olan bir yolcunun uçuş öncesi değerlendirmede dikkat edilmesi gereken özellikler sırasıyla; önceki seyahat anamnezi, hastalığın tipi, hastalı̆̆ın reverzibıl olup olmadığı ve fonksiyonel derecesi, hastanın yüksek irtifada uçma toleransı, tahmin edilen maksimum uçuş yüksekliği, uçuş süresi, uçuşun başlayacağı ve ulaşılacak havaalanının deniz seviyesinden yüksekliğinin yolcunun hastalığı üzerine etkisinin ne olacağı değerlendirilmelidir (9). Kardiyopulmoner hastallğ 1 olan yolcularda kabin içi hipoksi gelişmesi durumunda yolcunun ilave $\mathrm{O}_{2}$ tedavisinden fayda görüp görmeyeceği uçuş öncesi belirlenmelidir (9). Çok az derecede hipoksi durumunda ciddi kardiyopulmoner hastalığ 1 olan hastaların bir kısmı $\mathrm{O}_{2}$ tedavisi ile düzelebilir (9). Özellikle $\mathrm{KOAH}$ hastalarının baseline $\mathrm{pO}_{2}$ düşük olduğu için uçuş hipoksisine daha duyarlıdırlar, bronkodilatörler ve hiperventilasyonla oksijenizasyonu düzeltme yetenekleri oldukça kısıtlıdır ve uçuş sırasında ilave oksijen tedavisi gerekebilir. Bu hastaların uçuş öncesi değerlendirilmesi son derece önemlidir (9).

Pulmoner hastalığı olan yolcularda uçuş öncesi alınan anamnez, fizik muayene, rutin yapilan laboratuar testleri, deniz seviyesinde $\mathrm{SatO}_{2}$ düzeyi ve FEV1, solunumsal hastalığ olan yolculara havayoluyla seyahatin komplikasyonların, hipoksinin etkisini ve uçuşa uygunluğunun değerlendirilmesinde yeterli değildir $(9,12)$. Solunum fonksiyon testlerindeki anormallikler (vital kapasite, expirasyon akım hızı, tahmin edilen difüzyon kapasitesinin \%50 den az olması) akciğer rezervinin yetersiz olduğunun göstergesidir ve yolcuların daha ileri testlerle değerlendirilmesi gerekir (9).

Arteriyel kan gazı ölçümü ve $\mathrm{pO}_{2}$ değeri hastanın yüksek irtifada kabin içi düşük $\mathrm{pO}_{2}$ 'ye toleransını ve uçuş için uygunluğunu değerlendirmede kullanılacak en önemli yardımc1 testtir (9). Stabil bir hastada yer seviyesinde ölçülen kan gazında $\mathrm{p}_{2}>70 \mathrm{mmHg}$ olan yolcular, uçuş irtifasındaki düşük $\mathrm{pO}_{2}$ 'yi tolere edebilir ancak $\mathrm{pO}_{2}<70 \mathrm{mmHg}$ ise uçuş esnasında ilave oksijen 
tedavisi gerekebilir (2). Arteriyel kan gazın da $\mathrm{pCO}_{2}$ düzeyinin yüksek olması, hastanın pulmoner rezervinin kötü olduğunu ve yüksek irtifa uçuşlarında ilave oksijen tedavisi gerekebileceğini ve havayolu ile seyahatin riskli olabileceğini gösterir $(7,9)$.

Solunum sistemi hastalığı olan yolcuların havayolu ile seyahat süresince ilave $\mathrm{O}_{2}$ ihtiyacını ve uçuşa uygunluğunu belirleyen en önemli test ''Hipobarik Chamber Exposure'” testidir (16). Ancak her yerde bulunamadığ 1 için yerine Hipoksi Altitude Simulation Testi (HAST) veya Hypoxic Challenge Testi (HCT) kullanılır. HAST testinde yüksek irtifada uçuş esnasında uçak kabin içi ortamına benzer gaz karışımı solutularak $\mathrm{pO}_{2}$ belirlenir. HAST testinde $\mathrm{pO}_{2}<55 \mathrm{~mm} \mathrm{Hg}$ ise uçuş esnasında hastanın ilave $\mathrm{O}_{2}$ 'e ihtiyacı olabileceği düşünülmelidir (9). HCT testi hastanın uçuşa uygunluğunu belirlemez sadece hastanın uçuş sırasında $\mathrm{O}_{2}$ ihtiyacının belirlenmesinde kullanılır. HCT'de $\mathrm{FiO}_{2}=15 \%$ olacak şekilde $20 \mathrm{dk} \mathrm{O}$ hastaya solutulur. $\mathrm{pO}_{2}>50 \mathrm{~mm} \mathrm{Hg}$ veya $\mathrm{SatO}_{2} \geq 85 \%$ ise uçuş sırasında ilave $\mathrm{O}_{2}$ gerekli değildir. $\mathrm{PO}_{2}<50 \mathrm{~mm} \mathrm{Hg}$ veya $\mathrm{SatO}_{2}<85 \%$ ise uçuş süresince nazal kanülle 2 litre/dakika ileve $\mathrm{O}_{2}$ gereklidir (12). Ancak şu unutulmamalıdır ki Uçuş sırasında ileve $\mathrm{O}_{2}$ veya ventilatör desteği bile hastanın güvende olduğunu garanti etmez, bu tedavilerle hipoksiye bağlı semptomlar her zaman düzelmeyebilir (12).

$\mathrm{Bu}$ testlerin yapılamadığ 1 şartalarda en pratik test ise hastanın ciddi derecede solunum sikıntısı olmadan $50 \mathrm{~m}$ yürüyüp yürüyemediği veya bir kat veya 10 adım merdivenden çıkıp çıkamadığı değerlendirilmelidir $(2,9)$.

4.1- Kronik Obstriktif Akciğer Hastalığı (KOAH), Plevral Efüzyon ve Hemotoraks: Yer seviyesinde ilave $\mathrm{O}_{2}$ tedavisine ihtiyaç duyan, $\mathrm{pO}_{2}<50 \mathrm{mmHg}$ olan ve yakın zamandaki hastallk alevlenmesi tamamen iyileşmemiş hastalar uçuş öncesi havacılık tıbbı alanında tecrübeli doktorlarca değerlendirilmelidir (6). Deniz seviyesinde 4 litre/dk'dan fazla ilave $\mathrm{O}_{2}$ ihtiyacı olan hastaların havayolu ile seyehati kontrendikedir (12).

4.2-Pulmoner Emboli (PE): Pulmoner HT ve pulmoner embolisi olan hastalarda uçuş sırasındaki kabin içi hipoksi pulmoner vazokonstriksiyona, pulmoner HT'nun kötüleşmesine ve kardiyak outputda azalmaya neden olabilir (9). Bu hastaların uçuş süresince hareketlerini kısitlaması ve ileve $\mathrm{O}_{2}$ tedavisi alması önerilir. Akut PE olan ve uçuş öncesi geçen süre 4 günden az olan hastalar uçmamalıdır. Hastalık başlangıcından itibaren geçen süre 5 günden fazla ise, hasta antikoagülan tedaviyle stabilse ve oda havasında $\mathrm{pO}_{2}$ normal olan PE hastalarının uçmasında sakınca yoktur (6).

4.3-Pulmoner Hipertansiyon: NYHA (New York Heart Association) fonksiyonel sinıflaması II (hafif solunum sıkıntısı ve günlük fiziksel aktivitede hafif kıstlama) ve III (semptomlar yüzünden fiziksel aktivitede kısıtlanma, kısa mesafede yürüme (20-100 m) gibi günlük fizik aktiviteden daha az aktivitelerde bile semptomlar meydana gelen sadece istirahatte rahat semptom yok) olan hastalar uçuş öncesi havacılık tıbbı alanında tecrübeli doktor tarafından değerlendirilmelidir (6). NYHA fonksiyonel siniflamasi I olan hastalar (semptom yok, günlük fizik aktivitesinde kısıtlama yok, yürüdüğü zaman, merdiven çıktığı zaman solunum sıkıntısı yok) uçuşa kabul edilebilir $(6,12)$. NYHA fonksiyonel sinıflamsı IV (istirahatte bile semptomları meydana gelen yatağa bağımlı) olan hastalar hava tahliye protokolüne göre transfer edilmelidir.

4.4-Pulmoner Ödem: Pulmoner ödem düzelmeden hava seyehati sakıncalıdır. Pulmoner ödem düzelmişse ve herhangi presipite edici bir neden yoksa hastanın uçmasında sakınca yoktur. Bu hastaların Mİ yönünden ve Mİ için geçerli olan uçuş kurallarına görede değerlendirilmesi gerekebilir (6).

4.5-Astım; Hâlihazırda enfeksiyonu olmayan ve asemptomatik olan hastalar uçabilir. Ancak ihtiyaç halinde kullanması gereken astım ilaçlarını özellikle semptomların hızla hafiflemesini sağlayan inhalasyon ilaçlarını ve acil durumlarda kortikosteroid içerikli ilaçlarını yanlarında taşımalıdırlar $(6,9)$.

Yakın zamanda hastaneye yatış anamnezi olan, anstabil ve ciddi derecede astımlı hastaların uçması kontrendikedir (9).

4.6-Pulmoner Enfeksiyonlar: Aktif veya bulaşıcı solunum enfeksiyonu olan hastalar özellikle pulmoner tüberküloz hastaları uçuş için uygun değildir (9). Akut bakteriyel pnömonisi ve pnömoni semptomu olan hastalar havacılık tıbbı alanında tecrübesi olan doktor tarafından değerlendirilmelidir. Tamamen iyileşmiş, akciğer grafisinde bulgu olsada semptomları olmayan hastalar uçuşa kabul edilebilir (9). Yaşlı, uzun uçuş süresi olan ve yakın zamanda pnömoni hikayesi olan hastalar uçuş sırasında olası $\mathrm{O}_{2}$ ihtiyacı yönünden değerlendirilmelidir (6).

4.7- Plevral Efüzyonlar: Plevral efüzyon, özellikle büyük miktardaki plevral efüzyon uçuştan 14 gün önce drene edilmelidir (9). Torasentez sonrası göğüs radyografisiyle sivinın tekrar toplanması ve pnömotoraks açısından değerlendirilmelidir (9).

4.8- Pnömotoraks: Pnömotoraks, pnömomediastinum ve diğer extraalveolar hava mevcudiyetinin klinik belirtileri olan hastalar uçuş öncesi teşhis edilmeli ve tedavi edilmelidirler (9). Pnömotoraks uçuş için kesin kontrendikasyondur $(9,14)$.

Havanın tam rezorpsiyonu ve akciğerin tam havalanmasından sonraki geçen süre 6 günden az olan hastalar havacılık tıbbı alanında tecrübeli bir doktor tarafından değerlendirilmelidir (6). Daha erken dönemde uçuş gerekliyse ve hastanın genel durumu yeterliyse "Heimlich type" drenle ve sağlik personeli neazaretinde uçuşuna izin verilebilir. Spontan pnömotoraksda havanın tam rezorpsiyonu ve akciğerin tam havalanmasından sonra 7 gün geçen hastalar 
uçabilir (12). Travmatik pnömotoraksı olan hastalar hastalığın gelişiminden 14 gün sonra uçuşa kabul edilebilir $(6,12)$.

4.9-Akciğer Kanseri; Aktif tedavi altındaki (radyo/kemoterapi) hastalar, plevral efüzyonu olan, yer seviyesinde solunum sikıntısı olan hastalar havacilık tıbbı alanında tecrübeli bir doktor tarafindan değerlendirilmelidir. Asemptomatik hastalar uçuşa kabul edilebilir. Bu hastalarda major hemoptizi uçuş için kontrendikasyondur $(6,12)$.

\section{5-KULAK BURUN BOĞAZ HASTALIKLARI}

Uçuş esnasında maruz kalınan basınç değişikliklerine uyum sağlanması, uçağın kalkış ve inişi esnasında basınç eşitlenmesinin meydana gelmesi için diş kulak ve orta kulak pasajları tamamen açı olmalıdır $(9,17)$. Orta kulak boşluğundaki hava ağrı, başdönmesi, orta kulakta kanama, akıntı ve timpanik membran rüptürüne neden olabilir $(3,9,17)$.

5.1-Orta Kulak Enfeksiyonu; Orta kulak enfeksiyonu ve efüzyon, yakın zamanda geçirilmiş otolojik cerrahi operasyon hikayesi olan yolcular kulak burun boğaz (KBB) uzmanı tarafindan onay verilmeden uçmamalıdır (9). Orta kulak enfeksiyonu olan hastaların, östaki tüp fonksiyonu bozulmuşsa uçması kontrendikedir (3). Orta kulak enfeksiyonu, sinüzit, östaki tüp fonksiyon kaybı veya akut hastalığı olan hastalar havacılık tıbbında deneyimli bir doktor tarafindan değerlendirilmelidir. Kulaklarda proplem olmayan, valsalva esnasında timpanik membran hareketi görülebilen ve timpanometrisi normal olan yolcular uçabilir $(6,14)$.

Orta kulak cerrahisi (stapedektomi vb.) sonrası geçen süre 20 günden az olan hastalar havacılık tıbbında deneyimli doktor tarafindan değerlendirilmelidir. Orta kulak cerrahisi (stapedektomi) sonrası geçen süre 20 günden fazla olan hastaları KBB uzmanı tarafindan değerlendirildikten sonra uçuşuna onay verilmelidir (6).

5.2- İç Kulak/İntrakraniyal Cerrahi: Cerrahiden sonra 3 haftadan az zaman geçen yolcular, cerrahi girişimi yapan doktor tarafindan uçabileceğine dair rapor getirmelidir. İşlemi yapan doktor onay verirse ve operasyon sonrası geçen süre 21 günden fazla ise uçuşa izin verilebilir (6).

\section{3- Tonsillektomi, Adenoidektomi ve Nazal Cerrahi:}

Cerrahi işlemden sonraki geçen süre 13 günden az olan hastalar KBB uzmanı ve havacılık tıbbinda deneyimli doktor tarafından değerlendirlmelidir $(3,6,17)$. İki hafta geçen ve valsalva esnasında timpanik membranın doğrudan görülebilen veya normal timpanometrisi olan hastalar uçabilir (6). Tüm intranazal paketler (steroid salgilayan aletler gibi uzun dönem implantlar istisna) uçuş öncesi çıkarılmalıdır (6).

5.4- Basınç Eşitleme Tüpleri: Kulak tüpü yerleştirme veya basit miringotomi, orta kulağın havalanmasına yardım edeceği için aktif bir akıntı ya da tıkanıklık olmadığı sürece uçuş için kontrendike değildir ve aynı gün uçabilirler $(6,9,17)$. Diş kulak yolu kulak enfeksiyonları, kulak tıkaçları ve serümen ile havalanamayacak şekilde tıkanmışsa otaljiye neden olabilir. Kulak tıkaçlarını ve işitme cihazlarını gevşetme, uçuş öncesi kulak enfeksiyonları ve dış kulak yolu serumenlerini tedavi etme ile otalji önlenebilir $(9,17)$.

5.6-Burun ve Sinüsler; Akut ve kronik sinüzit, büyük polipler, yakın zamanda nazal cerrahi, tekrarlayan burun kanamaları, ciddi ÜSYE'si sinüs açıklıklarının tıkanmasına ve basınç eşitlenmesini önleyebileceği için uçuş kontrendikedir $(9,14,17)$. Bu durumlarda uçma ciddi baş ağrısı, fasiyal ağrı, sinüs enfeksiyonlarının orbita ve SSS'e yayılmasına ve kanamaya neden olabilir. Geniş spektrumlu antibiyotik (AB) tedavisi, mukolitik ajanlar, oral dekonjestanlar, steroidler, oksimetazolin gibi nazal dekonjestan spreyler nazal mukozayı küçülterek sinüs havalanması ve drenajını sağlayabilir. Serum fizyolojik sprey düşük nem yüzünden meydana gelebilecek burun kanaması ve nazal kurumayı azaltabilir $(9,17)$.

5.7-Diş Hastalıkları; Barodontalji uçak personelinde ve uçak yolcularında görülen, ani irtifa değişimlerinin yol açtığı yüksek basınç farkından kaynaklanan şiddetli diş ağrısıdır. Dolgu gibi yakın zamanda diş işlemleri genellikle uçuş için problem oluşturmaz. Ancak tedavi edilmemiş kök kanal tedavisi ve diş apsesi olan yolcular seyehat öncesi diş doktorunun önerilerini almalıdır (14). Anestezi gerektiren diş tedavisi yaptıran yolcular 24 saat uçmamalıdır (18). Cerrahi işlemle yapılan diş tedavisi sonrası 7 gün havayolu ile seyehat tavsiye edilmemektedir (18).

Diş çekimi ve diğer periodantal cerrahi sonrası birkaç saat ağız içi basınç değişiklikleri, kan pıhtısının yerinden ayrılmasına ve kanamaya neden olabilir, özellikle konuşma olmak üzere normal fonksiyonu bozabilir. Bu hastalrda semptomlar hafifleyinceye kadar 24-72 saat uçuş kısıtlaması önerilir (19). Barodentaljiden kaçınmak için diğer bir öneri ise yolcunun diş ağrısı olmadan rahat uyuyacak zamana kadar uçuş ertenlenmelidir (19).

\section{6-CERRAHI HASTALIKLAR}

Genel anestezi, altta yatan hastalıktan bağımsız olarak tek başına uçuş için kontrendikasyon oluşturmaz (genel anesteziklerin etkileri kısa sürede ortadan kalkar) (9). Spinal anestezi sonrası postsipinal baş ağrısı uçuş ile artabilir (kabin içi basınç değişiklikleri dural kaçağa sebeb olabilir) ve operasyon sonrası 7 . günde postsipinal baş ağrısı rapor edilmiştir (9).

Ticari yolcu uçaklarında kabin basıncı $8000 \mathrm{ft}$ yüksekliğe göre ayarlanır ve bu kabin basıncında deniz seviyesine göre gaz hacmi genişler. İntestinal gaz hacminde yaklaşık olarak \%25-40 artış olur. Asemptomatik küçük veya büyük barsak obstrüksiyonu olan hastalar uçuş sırasında gastrointestinal sistemdeki gaz genişlemesine uyum gösteremeyebilirler ve havayolu ile seyehat önerilmez (9). Abdominal cerrahi sonrası birkaç gün ileus tablosu sözkonusu olabilir 
$(9,11,12)$. İntestinal gaz hacmi genişlemesi sonucu bu hastalarda sütür hatlarında yırtılma, kanama, perferasyon riski sözkonusudur. Gastrik ve intestinal mukozada gerilme sütür veya ülser yerlerinden hemoraji ile sonuçlanabilir. $\mathrm{Bu}$ hastaların uçuşu 1-2 hafta ertelenmelidir $(3,9)$. Eğer abdominal cerrahi işlemde intestinal lümen açılmamışsa uçuşun ertelenme süresi 1 hafta kısaltılabilir.

Major abdominal cerrahi (barsak rezeksiyonu, açık histerektomi, renal cerrahi gibi) sonrası geçen süre 9 günden az olan hastalar uçmamalıdır. Komplikasyon gelişmeden iyileşen ve major abdominal cerrahi sonrası geçen süre 10 günden fazla olan hastalar uçabilir (6). Apendektomi sonrası geçen süre $\leq 4$ gün olan hastalar uçmamamalıdır. Komplikasyon gelişmeden iyileşen ve apendektomi sonrası geçen süre $\geq 5$ gün olan hastalar uçabilir (6).

Laparaskopik abdominal cerrahi girişimlerde açık operasyonlara göre daha az ileus sözkonusudur. Laparoskopik cerrahi sonrası geçen süre 4 günden az olan hastalar uçmamalıdır (6). Laparaskopik işlemi takiben intraabdominal kavitedeki rezidüel $\mathrm{CO}_{2}$ gazı hızla dokular içine difüze olur. Komplikasyon gelişmeden iyileşen, karın şişliği gibi semptomları geçen ve laparoskopik cerrahi sonrası geçen süre 5 günden fazla olan hastalar uçabilir $(6,9)$. Araştırmaya yönelik laparoskopi sonrası geçen süre 24 saatten az olan hastalar uçmamalıdır. Gaz absorbe olduktan sonra geçen süre 24 saatten fazla olan hastalar uçulabilir (6).

Kolonoskopik olarak polipektomi sonrasında polipektomi yerinde beklenmeyen bir kanama riskinden dolayı ve kolon içine büyük miktarda gaz verildiği için bu işlemi takiben 24 saat uçuş önerilmez (9).

Kolostomili yolcular, seyehat için risk taşımazlar. Ancak intestinal distansiyon fekal çıkışı artırabilir. Bu nedenle büyük kolostomi torbaları önerilir. Küçük torbalar kullanılırsa sık değiştirmek gerekebilir $(3,9)$.

Kraniyal cerrahi sonrasında kafa içinde tutulan gazlar, yükseklikte genişlediği zaman intrakraniyal basıncı artırabilirler. Travma sonrası veya herhangi bir girişim sonrasında kafa içind serbest hava olan hastalarda, gazın abzorbe olup olmadığını anlamak için kraniyal tomografi çekilmelidir. Kraniyal cerrahi sonrası geçen süre 9 günden az olan hastalar havacılık tıbbında tecrübeli doktorlar tarafindan uçuş öncesi değerlendirilmelidir. Kraniyal cerrahi sonrası geçen süre 10 günden fazla olan, kraniyal havası olmayan ve şikayeti kontrol altına alınmış hastalar doktor kontrolü sonrasında uçabilir (6).

Herhangi bir nedenle serebral sıvı kaçağı olan kişilerde, kabin içi basınç değişikliği geriye doğru akıma neden olarak mikrobiyal kontaminasyona neden olabileceği için bu yolcular uçmamalıdır (9).

Gögüs Cerrahisi (lobektomi, açık akciğer biyopsisi) sonrası geçen süre 10 günden az ise havacilık tıbbında deneyimli bir doktor tarafindan değerlendirilmeldir. Komplikasyon gelişmeksizin 11 günden fazla zaman geçen ve tamamen düzelen hastalar uçuşa kabul edilebilir $(6,15)$.

\section{7-ORTOPEDIK HASTALIKLAR}

Alçıdan yapılan atellerin altında hava bulunabileceği için, yüksek irtifada alçı altındaki hava genişlee ve 2448 saat içinde yapılan alçı sonrasında, özellikle uzun bacak alçıları, ekstremitede şişmeye neden olabilir. Tek parça, tam kat alçı yapılan hastalar, uçuş süresi 2 saatten fazla ise ve alçı sonrası geçen süre 48 saatten az ise uçmamalıdır $(2,3,6,15)$. Hastaya zarar verecek bir şişmenin olmaması için tam alçı değil de birbirinden ayrık iki parça halinde alçı kullanılması önerilir (17). Şişme atel kullanılmışsa, yüksek irtifada gaz genişlemesin etkisini azaltmak için bir miktar hava boşaltılmalıdır. Aksi taktirde dolaşım sıkıntısı ve nöropraksi gelişebilir $(9,17)$.

\section{8-GÖZ HASTALIKLARI}

Göz hastalıkları ve uçak yolculuğuna ilişkin iki muhtemel sıkıntılı durum vardır; 1-Kabin ortamındaki düşük nem, 2- Retinal ayrılma cerrahisindeki gibi postoperatif orbita içinde havanın kalması sonucu gelişebilecek muhtemel problemler (17).

Kontakt lens takan kişiler kuru kabin havasından rahatsızlık hissedebilirler. Göz yaşı lenslerin kayganlığının sağlanması yetersiz olabilir ve göz yaşı damlası kullanılması gerekir. Katarak cerrahisi ve sütürsüz lens implantasyonu sonrasında düşük nemli kuru hava gözlerin kaşınmasına ve yara yerinde kaçağa neden olabilir (17).

Retinal ayrılma cerrahisi gibi oftalmolojijk girişimler de geçici olarak intraokuler basıncı artırmak için intraokular gaz enjeksiyonu yapilır. Bu nedenle retina cerrahisi sonrasında intraoküler gaz kabarcıkları vitreusun hacminin \%30 altına ininceye kadar uçuş kontendikedir. İntra-okular cerrahi sonrası geçen süre 6 günden az ise hastalar uçmamalıdır. Yedi günden fazla zaman geçmişse ve glop içinde herhangi bir gaz kalmamışsa hasta uçabilir. Kullanılan gaz sülfürheksaflorid ise bu süre yaklaşık olarak 2 hafta, perfloropropan ise 6 haftaya kadar uzayabilmektedir $(6,17)$.

Penetre göz yaralanmalarında, yaralanma sonrası geçen süre 6 günden az olan hastalar uçmamalıdır. Yaralanma sonrası geçen süre 7 günden fazla ise ve glop içinde herhangi bir gaz kalmamışsa uçuşa izin verilebilir $(3,6)$.

Katarak cerrahisi sonrası geçen süre 24 saatten az olan hastalar uçmamalıdır. Katarak cerrahisi sonrası geçen süre 24 saatten fazla ise hastalar uçabilir. Korneal lazer cerrahisi sonrası geçen süre 24 saatten az olan hastalar uçmamalı, 24 saat sonrası ise uçabilir (6).

Uçak tutması olan hastaların intraokuler göz operasyonu sonrasında hemen uçmaması önerilir. Kusma ve öğürme yara yerinde rüptüre neden olabilir (17). 


\section{9-NÖROLOJIKK HASTALIKLAR}

9.1-Epilepsi: Genel olarak epilepsi hastaları güvenli şekilde uçabilir (3). Kontrol edilemeyen sık nöbet geçiren hastalar uçuş öncesinde iyi değerlendirilmelidirler. S1k nöbet geçiren ancak kontrol edilebilen nöbetleri olan hastaların refakatçi eşliğinde uçuş yapmasına izin verilebilir. Uçuş esnasında meydana gelen yorgunluk, öğünlerde gecikme, hipoksi, alkol kullanımı, jetlag gibi sirkadiayan ritm bozulmaları nöbet eşiğini düşürebilir (9).

Epileptik nöbet sonrası geçen süre 24 saatten az olan hastalar uçuş öncesi havacılık tıbbında tecrübeli doktorlar tarafindan değerlendirilmelidir $(2,3,6)$. Kontrol altına alınmış epilepsi hastaları epileptik nöbet sonrası geçen süre 24 saatten fazla ise uçabilirler $(2,3,6,12)$.

9.2-Trans İskemik Atak (TİA): TİA sonrası geçen süre 2 günden az olan hastalar uçuş öncesi havacılık tıbbında tecrübeli doktorlar tarafından değerlendirilmelidir. TİA sonrası geçen süre 2 günden fazla olan ve TİA'ya yönelik yapılan ileri tetkiklerde proplem olmayan hastaların uçmasında sakınca yoktur (6).

9.3- Serebrovasküler Olay (SVO): SVO sonrası geçen süre 4 günden az olan hastalar havacılık tıbbında tecrübeli doktorlar tarafindan uçuş öncesi değerlendirilmelidir. SVO sonrası iyileşen hastalar ilk 10 gün içinde seyahat etmemelidir. Ancak SVO sonrası geçen süre 5-14 gün olan hastalar stabilse veya iyileşmişse sağlık personeli eşliğinde uçmalıdır (2). İnme sonrası ilk 2 hafta içinde uçacak yolcular $\mathrm{O}_{2}$ ihtiyacı yönünden değerlendirilmelidir. Herhangi bir komplikasyon meydana gelmeden iyileşen hastaların yanında sağlık personeli refakatine gerek yoktur (6).

\section{0-ANEMI}

10.1-Gastrointestinal Sistem Kanaması: Kanamayı takiben geçen süre 24 saatten az ise hasta uçmamalıdır. Kanamayı takiben geçen süre 10 günden fazla olan hastalar uçabilir. Kanama sonrası 1-9 günlük dönemde endoskopide kanama belirtileri yoksa veya iyileşmenin net bulguları (Hb artışı gibi) olan hastalar uçabilir (6).

Kronik anemi dişındaki herhangi bir nedenle hemoglobin $(\mathrm{Hb})$ değeri $\leq 8.5 \mathrm{gr} / \mathrm{dl}$ 'nin altında olan hastalar uçmamalıdır (17). Akut gelişen ve $\mathrm{Hb}$ değeri $\geq 8.5 \mathrm{~g} / \mathrm{dl} \quad(5.3 \mathrm{mmol} / \mathrm{L})$ olan hastaların kan kaybı kesilmesini takiben 24 saat geçtikten sonra $\mathrm{Hb}$ değerleri kontrol edilmelidir. $\mathrm{Bu}$ hastaların uçuş sırasında $\mathrm{O}_{2}$ ihtiyacı olup olmayacağı mutlaka değerlendirilmelidir $(6,17)$.

10.2-Sickle Cell Anemi; Normal sivil hava yolu uçuşlarındaki uçuş yüksekliği genelde problem olmaz. Ancak irtifanın arttığı durumlarda oluşabilecek düşük oksijen basıncı krizi tetkleyebilir. En son kriz üzerinden geçen süre 9 günden az olan hastalar uçmamalıdır $(3,6)$. Kriz üzerinden geçen süre 10 günden fazla olan hastalar uçabilir (3). Yakın zamanda geçirilmiş kriz anamnezi olan hastaların uçuş sırasında $\mathrm{O}_{2}$ 'e ihtiyacı olup olmadığı mutlaka değerlendirilmelidir (6). Yaşamı tehdit eden krizler yüzünden bu hastalara $\mathrm{O}_{2}$ kaynağ olmadan seyehat etmemesi tavsiye edilir.

\section{1-GEBE HASTALAR}

11.1-Komplikasyonsuz Tek Gebelikler; Gebelik süresi < 36 hafta olan hastalar için uçuş raporu gerekli değildir $(6,14,15)$. Gebelik süresi $>36$ hafta olan gebe hastalar havacilık tıbbında tecrübeli bir doktor tarafından değerlendirilmelidir $(2,6,14)$.

11.2-Komplikasyonsuz Çoklu Gebelikler; Gebelik süresi $>32$ hafta olan gebe hastalar havacılık tıbbında tecrübeli bir doktor tarafından değerlendirilmelidir $(2,6)$. Gebelik süresi $<32$ hafta olan hastaların uçuşa uygunluk raporuna gerek yoktur $(6,15)$.

11.3-Düşük Tehdidi veya Komple Düşük; Aktif kanaması olan hastalar havacılık tıbbında tecrübeli bir doktor tarafindan değerlendirilmelidir (6). Stabil olan veya en az 24 saat ağrısı ve kanaması olmayan hastalar uçuşa kabul edilebilir (6).

\section{2-ÇOCUK YOLCULARLA SEYAHAT}

Yeni doğan ve çocuklar için havayolu ile seyahat genellikle problem teşkil etmez ancak doğumdan sonra çocuğun sağlıklı olduğundan, akut solunum sıkıntısı veya konjenital defekt olmadığından ve alveollerin tam genişlediğinden emin olmak için 1-2 hafta beklenmesi önerilir (9). Yeni doğan çocuklar 48 saatten küçük ise havacılık tıbbında tecrübeli bir doktor tarafindan değerlendirilmelidir (6). Sağlıklı bebeklerin doğumundan sonraki geçen süre 48 saatten fazla ise uçabilir ancak 7 günden sonra uçması tercih edilir $(6,9,14,15)$.

Yeni doğanlarda ve yürümeye yeni başlayan çocuklarda östaki tüp fonksiyonu genellikle kötüdür ve orta kulak enfeksiyonu sıktır. Bu durum iniş esnasında kulak ağrısı riskini artırır. ÜSYE ve burun tıkanıklığ 1 olan çocuklara inişten $30 \mathrm{dk}$ önce nazal dekonjestan uygulanması faydalı olabilir (9). Orta kulak enfeksiyonu olan çocuklara uçuştan en az 36 saat önce antibiyotik başlanmışsa ve östaki tüp fonksiyonu normalse uçmasında sakınca yoktur (9). Çocukların meme veya şişeden beslenmesi, yalancı meme emmesi, büyük çocukların kupadan su içmesi östaki tüpünün açılmasında faydalıdır (5).

\section{3-PSIKIIYATRIK HASTALIKLAR}

Psikiyatrik hastalık sonucu nasıl davranacağı tahmin edilemeyen, agresif, dezorganize, kargaşaya yol açan ve güvenlik açısından sıkıntıya neden olabilecek hastaların uçuşuna izin verilmemelidir $(3,14)$ İlaçla kontrol edilen kronik psikozlu hastaların, hastalık hakkında bilgili birsinin refakatiyle uçuşuna izin verilebilir (2).

Delüzyon, paranoid davranış, agresif davranış, dezoryantasyon, ajitasyon, bilindik bir çevrede ajitasyon, endişe ve önemli anksiyetesi olan hastalar havacılık tıbbında tecrübeli doktorlar tarafindan uçuş öncesi değerlendirilmelidir (6). Toplumda herhangi bir fonksiyonel bağımlılığı olmadan yaşayan ve hafif 
düzeyde kognitif bozulması olan hastaların uçmasında herhangi bir sakınca yoktur. Paronoya, agresif davranış, endişe ve ajitasyonu olmayan hastalar uçabilir. Yakın zamanda yapılan uçuş sonrası kötüleşmeyen ve genel durumunda değişiklik olmayan hastalarda uçabilir (6).

13.1-Akut Psikoz; Son 30 gün içinde akut psikoz tanıs1 hastalar (manik, şizofreni ve ilaca bağlı vb) havacılık tıbbında tecrübeli doktorlar tarafından uçuş öncesi değerlendirilmelidir (6).

13.2-Kronik Psikiyatrik Hastalıklar: Uçuş süresince kötüleşmesi riski olan psikiyatrik hastaların havacılık tıbbında tecrübeli doktorlar tarafindan uçuş öncesi değerlendirilmelidir (6). Hastanın psikiyatrik hastalığı uçuş öncesi ilaçla kontrol altına alınmışsa ve stabilse (ilaç dahil olmak üzere tüm ihtiyaçları karşılayarak toplumda yaşayabiliyorsa) uçmasında sakınca yoktur $(2,6)$.

\section{4-DEKOMPRESYON HASTALIĞI}

Dekompresyon Hastalığı (DKH); Dalgıçlık gibi spor hobisi olanlar ve mesleği dalgıçlık olanlarda dalma esnasında yüksek basınca maruz kalındıktan kısa bir süre sonra yüzeye çıkarken kurallara uyulmazsa ve düşük basınca maruz kalınması sonucu farklı dokulardaki küçük kabarcıklar halinde çözünen aşırı nitrojenin açığa çıkmasıyla hava embolisi ve DKH meydana gelir. Dalış sonrasında kısa bir süre içinde olsa uçakla seyahat yapan yolcularda DKH'nın gelişme riski vardır. Semptomlar eklem ve kas ağrısı şeklinde hafif olabileceği gibi, pulmoner emboli, nörolojik disfonksiyonla sonuçlanabilir (9).

Dalış öncesi DKH gelişmeyen ve DKH gelişen hastaların uçuş öncesi değerlendirilmesi farklıdır.

14.1-DKH Gelişmeyen Yolcular; Dalış sonrasında DKH gelişmeyen bir kişinin ne kadar süre bekledikten sonra uçmasının güvenli olduğu kesin olarak belli değildir (9). Hergün bir defa dalan kişi, yüksek bir noktaya çıkmadan önce (otomobil, uçak vs ile) minumum 12 saat beklemelidir (9). Her gün çok sayıda dalış yapan veya dekompresyon gerektiren dalgıçlar yüksek bir noktaya çıkmadan önce ve havayolu ile seyahatten önce 24 saat beklemelidirler. Uzun bir tatil süresince aşırı şekilde dalan, hobi amaçlı dalış sporuyla ilgilenen ve $30 \mathrm{ft}$ 'den derine dalış yapan yolcuların denitrojenizsayon için uzun süre beklemesi ve son bir gününü dalışsız olarak geçirmesi, uçuşlarını 24-48 saat geciktirmeleri önerilir $(2,9,14,15)$.

14.2-DKH Gelişen Yolcular: Dalış sonrası DKH gelişen bir kişinin uygun bir tedavi almadan uçması kontrendikedir $(9,14)$. Tedavi edilmemiş veya semptomatik vakalar havacılık tıbbında tecrübeli doktor tarafından değerlendirilmelidir. DKH gelişen ve tedavi edilen hastalar, tedavi sonrası 72 saat geçtikten sonra sualtı tıbbı uzmanı doktor tarafindan değerlendirildikten sonra uçması önerilir (6).

\section{Çıkar İlişkisi}

Tüm yazarlar çıkar çatışması olmadığını beyan eder.

\section{KAYNAKLAR}

1. Sayılarla Türk Hava Yolları - Turkish Airlines. https://www.turkishairlines.com/tr-int/basin- odasi/hakkimizda/sayilarla-turk-hava-yollari/ 7 Temmuz 2020'de erişildi.

2. Johnston R. Clinical aviation medicine: safe travel by air. Clin Med (Lond). 2001;1(5):385-388.

3. British Airways Health Services, Your Patıent And Air Travel, A Guide To Physicians. https://www.britishairways.com/health/docs/before/airtravel_guide.pdf 7 Temmuz 2020'de erişildi.

4. Qureshi A, Porter KM. Emergencies in the air. Emerg Med J. 2005;22(9):658-9.

5. Silverman D, Gendreau M. Medical issues associated with commercial flights. Lancet. 2009;13;373(9680):2067-77.

6. Medical Manual for Aviation, June 2018,11th Edition. https://www.iata.org/en/publications/medical-manual/ 1 Haziran 2020'de erişildi.

7. Ergan B, Akgun M, Pacilli AMG, Nava S. Should I stay or should I go? COPD and air travel. Eur Respir Rev. 2018 Jun 13;27(148):180030.

8. DeHart RL. Health issues of air travel. Annu Rev Public Health. 2003;24:133-151.

9. Aerospace Medical Association Medical Guidelines Task Force. Medical Guidelines for Airline Travel, 2nd ed. Aviat Space Environ Med. 2003;74(5 Suppl):A1-A19.

10. Lee AP, Yamamoto LG, Relles NL. Commercial airline travel decreases oxygen saturation in children. Pediatr Emerg Care. 2002;18(2):7880.

11. Fitness to travel by air. In: Harding RM, Mills FJ (eds). Aviation medicine. Br Med J 1993.

12. Ahmedzai S, Balfour-Lynn IM, Bewick T, Buchdahl R, Coker RK, Cummin AR, et al. Managing passengers with stable respiratory disease planning air travel: British Thoracic Society recommendations. Thorax. 2011;66 Suppl 1:i1-i30.

13. Mangili A, Gendreau MA. Transmission of infectious diseases during commercial air travel. Lancet. 2005;365(9463):989-996.

14. Air travel advice. Who should avoid air travel for health reasons? https://www.who.int/news-room/q-a-detail/air-travel-advice. 4 Temmuz 2020'de erişildi.

15. Johnston R. Clinical aviation medicine: safe travel by air. Clin Med (Lond). 2001;1(5):385-388.

16. British Thoracic Society Standards of Care Committee. Managing passengers with respiratory disease planning airtravel: British Thoracic Society recommendations. Thorax. 2002;57(4):289-304. 


\section{Ceyhan et al.}

17. Aerospace Medical Association. Fitness to Fly and Medical Clearances. http://www.asma.org/publications/medical-publications-for-airlinetravel/medical-considerations-for-airline-travel. 4 Temmuz 2020'de erişildi.

18. Goethe WH, Bäter H, Laban C. Barodontalgia and barotrauma in the human teeth: findings in navy divers, frogmen, and submariners of the Federal Republic of Germany. Mil Med. 1989;154(10):491-5.

19. Zadik Y. Aviation dentistry: current concepts and practice. Br Dent J. 2009;206(1):11-16. 